\title{
V.M. Gun'ko \\ CHARGE DISTRIBUTION FUNCTIONS FOR CHARACTERIZATION OF COMPLEX SYSTEMS
}

\author{
Chuiko Institute of Surface Chemistry of National Academy of Sciences of Ukraine \\ 17 General Naumov Str., Kyiv, 03164,Ukraine, E-mail: vlad_gunko@ukr.net
}

\begin{abstract}
A set of characteristics calculated within the scope of quantum chemistry methods may be assigned to local ones changing from atom to atom in complex systems. Simple averaging of the related values gives rather poor characteristics of the systems because various fractions of certain atoms can have different surrounding and, therefore, different characteristics, which may not correspond to the average one. The aim of this study is searching a more appropriate pathway to transform local characteristics, e.g., atomic charges, into nonlocal ones based on the distribution functions. The distribution functions of atomic charges (CDF) could be considered as a simple tool to analyze nonuniform complex systems since specificity of different fractions of atoms reflects in the CDF shape. As a whole, the approach accuracy and efficiency depend on the quality and appropriateness of molecular and cluster models used, as well as on the quantum chemical methods (ab initio, DFT, and semiempirical) and the basis sets used. Nanosystems with dozens of molecules (clusters, domains, nanodroplets), modelling a liquid phase or interfacial layers, and solid nanoparticles of almost real sizes $(>40$ units, $>2 \mathrm{~nm}$ ) may be considered as more appropriate models of real systems than the models with several molecules and small clusters $(<20$ units, $<1 \mathrm{~nm})$. This approach has been applied to a set of representatives of such various materials as activated carbon, porous and nanoparticulate silicas unmodified and modified interacting with nitrogen, methane, water, human serum albumin (HSA) binding doxorubicin molecules. This approach may give information useful upon the analysis of any complex system.
\end{abstract}

Keywords: atomic charges, distribution functions, DFT method, semiempirical method

\section{INTRODUCTION}

According to quantum chemical calculations, the electronic characteristics of molecular and cluster systems could be divided into local (e.g., atomic charges, magnetic shielding tensors or chemical shifts, bond length, strength and vibrations, etc.) and nonlocal (molecular orbitals, $\mathrm{MO}$, electron bands, total energy, solvation energy, etc.) ones [1-9]. Some of the latter may be represented as local or quasi-local characteristics (e.g., localized MO, spin density, etc.). On the other hand, the transformation of the local characteristics into nonlocal ones is of interest to obtain a more generalized picture of the electronic structure, to analyze various phenomena and related experimental data, etc. [10-13]. In the present work, this transformation was realized for values of atomic charges $(q)$. This was done upon calculations of interfacial structures with water, methane, nitrogen, and human serum albumin (HSA) binding doxorubicin (DOX) interacting with nanoparticles of unmodified and modified silicas, alumina, alumina/silica, titania/silica, and activated carbon as representatives of different systems using the density functional theory (DFT) and semiempirical (PM7) methods [14, 15].

\section{CALCULATION METHODS}

Solid nanoparticles, free water clusters and interfacial layers at surfaces of hydrophilic and hydrophobic silicas, alumina, alumina/silica, and titania/silica were calculated using DFT methods with the Gaussian 09 [14] and GAMESS 2020 R2 [15] program suits. The DFT calculations were done using a hybrid functional $\omega \mathrm{B} 97 \mathrm{X}-\mathrm{D}$ and $\mathrm{cc}-\mathrm{pVDZ}$ basis set. The solvation effects were analyzed using the SMD method [16] implemented in the Gaussian and GAMESS. The calculations were performed taking into account zero-point and thermal corrections to the Gibbs free energy in the gas phase and for solvated molecules and silica clusters using the geometry optimized using $\omega B 97 X-D / c c-p V D Z$ (with or without SMD). Note that $\omega \mathrm{B} 97 \mathrm{X}-\mathrm{D}$ introduces empirical damped atompairwise dispersion terms into the functional containing range-separated Hartree-Fock exchange for better description of van-der-Waals interactions $[17,18]$. Therefore, $\omega \mathrm{B} 97 \mathrm{X}-\mathrm{D}$ was selected to obtain more adequate results for the gas and liquid phases (water, hydrophilic and hydrophobic organic solvents) interacting with hydrophilic and hydrophobic silica nanoparticles. Large systems up to 15200 atoms were calculated using the PM7 
method (MOPAC 2016, versions 20.015L, 20.268L, and 21.002L) [19, 20].

The distribution functions of atomic charges (CDF) were calculated using a simple equation [10-13]

$f_{n}(q)=\left(2 \pi \sigma_{n}^{2}\right)^{-0.5} \sum_{j} \frac{\exp \left[-\left(q_{n, j}-q\right)^{2}\right]}{2 \sigma_{n}^{2}}$,

where $j$ is the number of an atom of the $n$-th kind, $\sigma_{\mathrm{n}}^{2}$ is the distribution dispersion for the atoms of the $n$-th kind, and $q_{n, j}$ is the Mulliken charge value, and $q$ is the current value. For the electron-donor atoms $(\mathrm{H}, \mathrm{Al}, \mathrm{Si}, \mathrm{Ti}), \sigma=0.01$ a.u., and $\sigma=0.05$ a.u. for electron-acceptor atoms (C, N, O, $\mathrm{S})$. This difference in the $\sigma$ values is due to broadening of the CDF for atoms with excess electron density (i.e., for electron-acceptor atoms) more strongly affected by the surroundings in comparison to the atoms with deficiency in the electron density (electron-donor atoms) with more compact electron clouds. Additionally, the distribution functions of integral density of electron states (IDES) of some silica clusters were calculated using an equation similar to Eq. (1) with

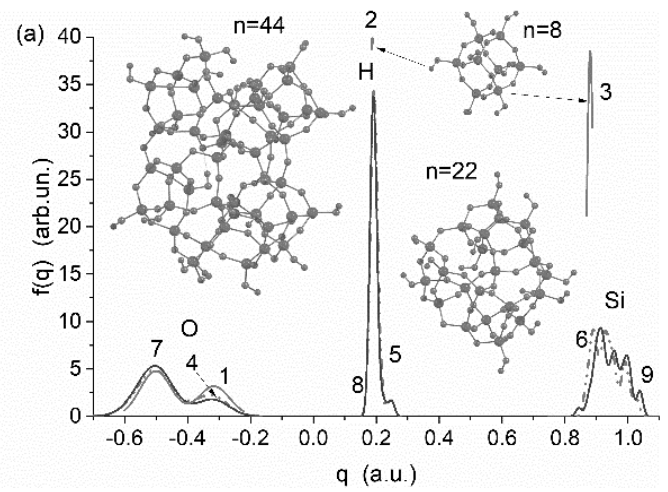

the molecular orbital energy $(E)$ instead of the atomic charge, $q[21]$.

\section{RESULTS AND DISCUSSION}

The CDF shapes for silica clusters at 8, 22, and 44 units (Fig. 1 a) show that the curves for the smallest cluster are incomplete and simpler than those for larger silica models with the same $\sigma$ value. As a whole, the CDF shapes are quite appropriate for the cluster at $n=44$ since the curves give information on a difference in the $\mathrm{O}$ atoms in the siloxane bridges and silanols, $\mathrm{H}$ atoms without or with the hydrogen bonds, as well as for the $\mathrm{Si}$ atoms with different surroundings. Thus, one may assume that silica clusters at $n>40(>2 \mathrm{~nm}$ in size) could be considered as appropriate models of silica nanoparticles. Additionally, a set of the CDF (Fig. $1 a$ ) is more informative and sensitive to the cluster size than the IDES (Fig. $1 b$ ). However, instead of the IDES local DES (i.e., local density of electron states for each atom in the system) could be calculated that give detailed but purely local pictures of the electron states of complex systems [21]. Therefore, the IDES/LDES are not considered here as a tool to transform the local characteristics into nonlocal ones.

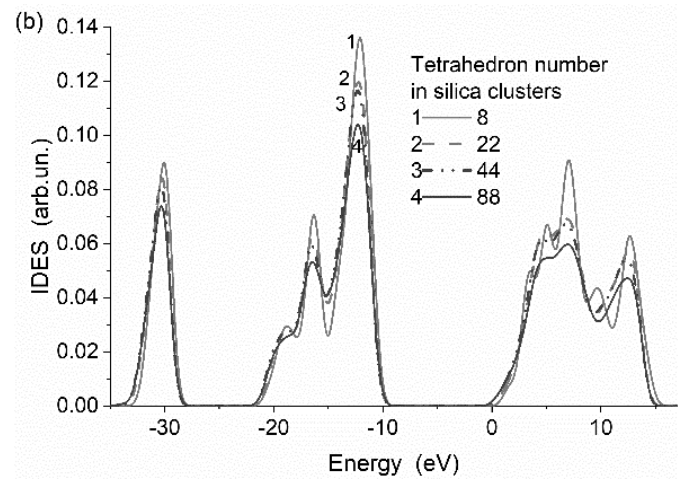

Fig. 1. Distribution functions of ( $a$ ) charges of $\mathrm{H}$ (curves $2,5,8), \mathrm{O}(1,4,7)$, and $\mathrm{Si}(3,6,9)$ atoms for silica clusters with 8 (curves 1-3), 22 (4-6), and 44 (7-9, size $\sim 2 \mathrm{~nm}$ ) $\mathrm{SiO}_{4 / 2}$ units and silanols (solid lines at $n=8$ and 44 , and dashed lines at $n=22) ;(b)$ integral density of electron states for the same silica clusters calculated using the $\omega \mathrm{B} 97 \mathrm{X}-\mathrm{D} / \mathrm{cc}-\mathrm{pVDZ}$ method

Upon the adsorption of nitrogen molecules $\left(40 \mathrm{~N}_{2}\right)$ onto the cluster at $n=44$, the maximal difference in the CDF calculated using the DFT and PM7 methods is observed for the $\mathrm{H}$ atoms (Fig. 2), since for others $(\mathrm{N}, \mathrm{O}$, and $\mathrm{Si})$ the positions of the CDF peaks are close. However, the calculations with the PM7 method give less detailed CDF curves; i.e., the electronic structure of the atoms is less sensitive to the surroundings upon calculations with only the valence basis (PM7). This aspect also appears upon the calculations of the NMR spectra with the DFT (or ab initio) methods and estimation of the ${ }^{1} \mathrm{H}$ NMR spectra $\left(\delta_{\mathrm{H}}\right)$ using calculations with the PM7 (or PM6, etc.) method $\left(q_{\mathrm{H}}\right)$ and correlation functions for $\delta_{\mathrm{H}} v s . q_{\mathrm{H}}[10-13,22]$. This approach does not work for non-hydrogen multi-electron 
atoms. One of the reasons of this restriction is the use of the MO only of valence electrons with frozen core electrons in the semiempirical methods (PM7, etc.). Thus, if it is possible that the use of the DFT methods is preferable than the use of the semiempirical methods to study various complex systems.

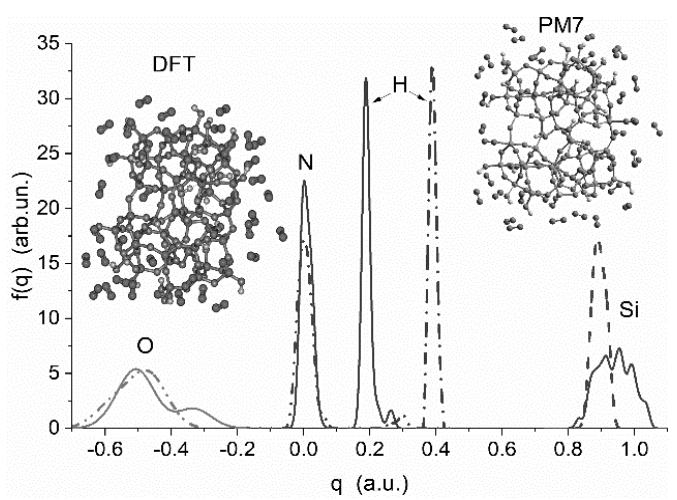

Fig. 2. Charge distribution functions of $\mathrm{H}, \mathrm{N}, \mathrm{O}$, and $\mathrm{Si}$ atoms for a silica cluster $\left(44 \mathrm{SiO}_{4 / 2}\right.$ units and $24 \mathrm{OH})$ and adsorbed nitrogen molecules $\left(40 \mathrm{~N}_{2}\right)$ calculated using the $\omega$ B97X-D/cc-pVDZ (solid lines) and PM7 (dashed lines) methods

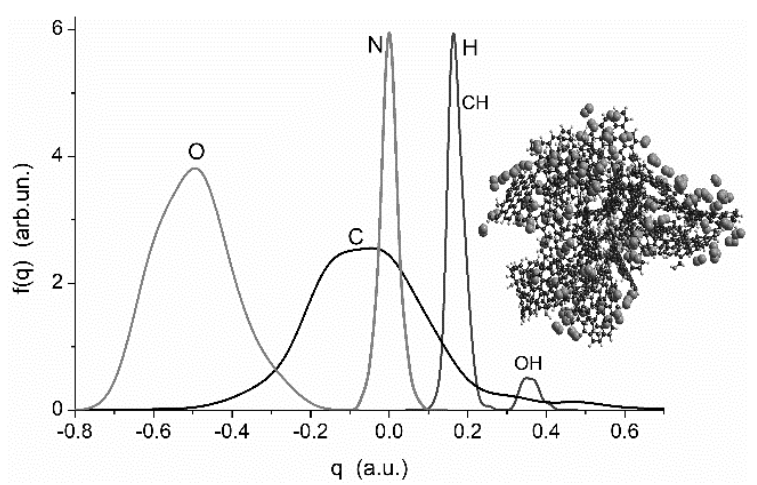

Fig. 3. Charge distribution functions of $\mathrm{H}, \mathrm{C}, \mathrm{N}$, and $\mathrm{O}$ atoms for a model cluster (1787 atoms in total) of activated carbon decorated by various O-containing functionalities and adsorbed nitrogen molecules (see insert)

Comparison of the CDF of the nitrogen atoms upon the adsorption of nitrogen molecules onto silica clusters (Fig. 2) and AC (Fig. 3) shows that in the case of a more polar surface of silica, there is certain asymmetry in the CDF with a larger contribution of $q_{\mathrm{N}}>0$ due to transfer of the electron density toward the silica surface (e.g., onto $\mathrm{H}$ in the $\mathrm{SiOH}$ groups). For the latter, the $q_{\mathrm{H}}$ values are greater than that for AC. This effect leads to stronger variations in the orientation of the $\mathrm{N}_{2}$ molecules at a silica surface, and, therefore, the occupied area for $\mathrm{N}_{2}$ adsorbed onto silica could be smaller $\left(0.135-0.137 \mathrm{~nm}^{2}\right)$ than that upon the adsorption onto basal planes of carbons $\left(0.162 \mathrm{~nm}^{2}\right)$.

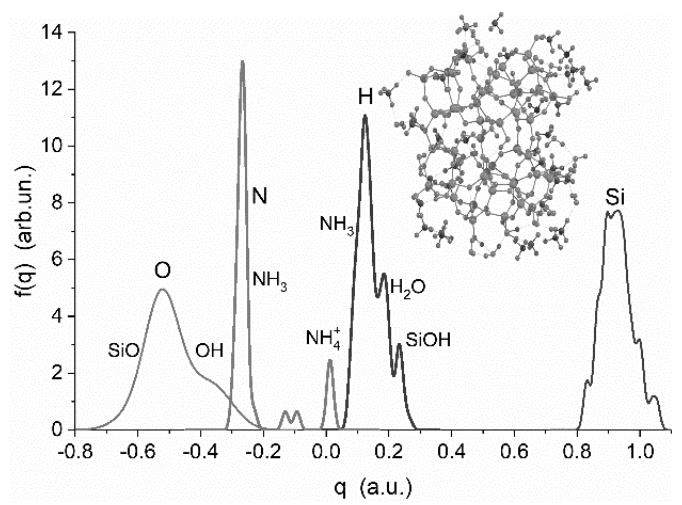

Fig. 4. Charge distribution functions of $\mathrm{H}, \mathrm{N}, \mathrm{O}$, and $\mathrm{Si}$ atoms for silica cluster (44 units $+19 \mathrm{OH}$ and $\left.5 \mathrm{SiO}^{-}\right)$and adsorbed $\mathrm{NH}_{3}\left(5 \mathrm{NH}_{4}{ }^{+}\right.$and $\left.30 \mathrm{NH}_{3}\right)$ and $16 \mathrm{H}_{2} \mathrm{O}$ molecules calculated using the $\mathrm{SMD} / \omega \mathrm{B} 97 \mathrm{X}-\mathrm{D} / \mathrm{cc}-\mathrm{pVDZ}$ method

The CDF of the $\mathrm{O}$ atoms are broader for $\mathrm{AC}$ than for silica (PM7 method) because of a larger variety in the surroundings of the $\mathrm{O}$ atoms in $\mathrm{AC}$ than in silica.

The appearance of charged groups $\left(\mathrm{SiO}^{-}\right)$and ions $\left(\mathrm{NH}_{4}^{+}\right)$more strongly affects the $\mathrm{CDF}$ of $\mathrm{N}$ and $\mathrm{H}$. This result is due to significant localization of the excess charges in solvated or adsorbed ions in comparison to the charged groups at a surface of solids (Fig. 4).

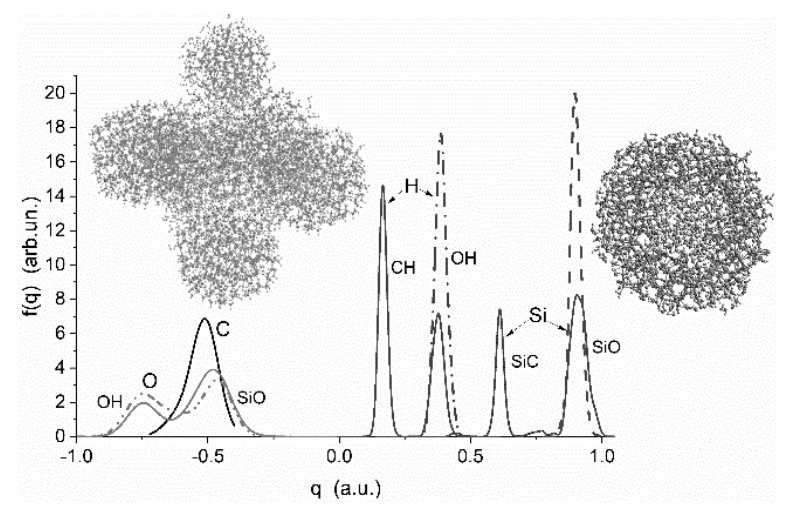

Fig. 5. Charge distribution functions of $\mathrm{H}, \mathrm{C}, \mathrm{N}, \mathrm{O}$, and $\mathrm{Si}$ atoms for silica nanoparticles (unmodified, A-300 and modified by dimethylsilyl groups paircrosslinked, AM1, forming aggregate with six nanoparticles AM1/A-300 at 5:1, 8090 atoms in total), and pore model (pore radius $R=0.9 \mathrm{~nm}$, 3171 atoms in total) of unmodified silica gel and adsorbed $\mathrm{H}_{2} \mathrm{O}$ and $\mathrm{CH}_{4}$ (only on AM1/A-300 aggregate) molecules calculated using the PM7 method 
The silica particle structure (particulate or porous) weakly affects the $\mathrm{CDF}$ of the $\mathrm{H}, \mathrm{C}, \mathrm{O}$, and $\mathrm{Si}$ atoms (Fig. 5). This result may be explained by a major contribution of atoms with similar surroundings in the particles of different morphologies. This assumption is confirmed by the calculations of complex systems (Figs. 6 and 7). The

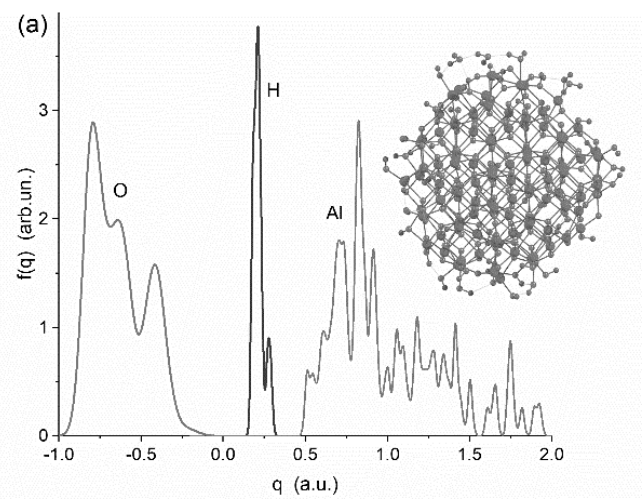

surroundings of the $\mathrm{Al}$ atoms are different in $\gamma-\mathrm{Al}_{2} \mathrm{O}_{3}$ (Fig. 6 a) and alumina embedded into silica, AS (Fig. $6 b$ ) due to variations in the O-coordination numbers of $\mathrm{Al}$ (from 3 to 6 for $\gamma-\mathrm{Al}_{2} \mathrm{O}_{3}$ and only 4 for alumina at a silica surface). This difference leads to a complex $\mathrm{CDF}$ of $\mathrm{Al}$ in $\gamma-\mathrm{Al}_{2} \mathrm{O}_{3}$ in contrast to $\mathrm{AS}$ (Fig. 6).

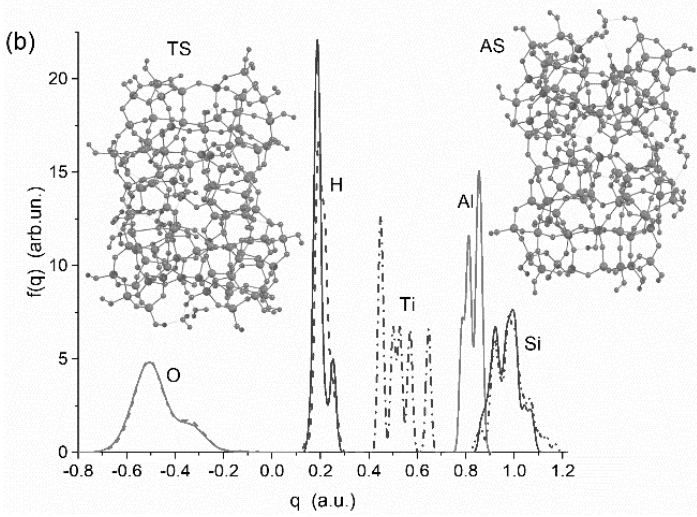

Fig. 6. Charge distribution functions of $\mathrm{H}, \mathrm{O}, \mathrm{Al}, \mathrm{Si}$, and $\mathrm{Ti}$ atoms for clusters and adsorbed $\mathrm{H}_{2} \mathrm{O}$ molecules calculated using the $\omega \mathrm{B} 97 \mathrm{X}-\mathrm{D} / \mathrm{cc}-\mathrm{pVDZ}$ method: (a) $\gamma-\mathrm{Al}_{2} \mathrm{O}_{3}\left(363\right.$ atoms) and (b) silica ( 82 units +40 hydroxyls $+10 \mathrm{H}_{2} \mathrm{O}$ ) with six units of alumina (AS, solid lines) or titania (TS, dashed lines)

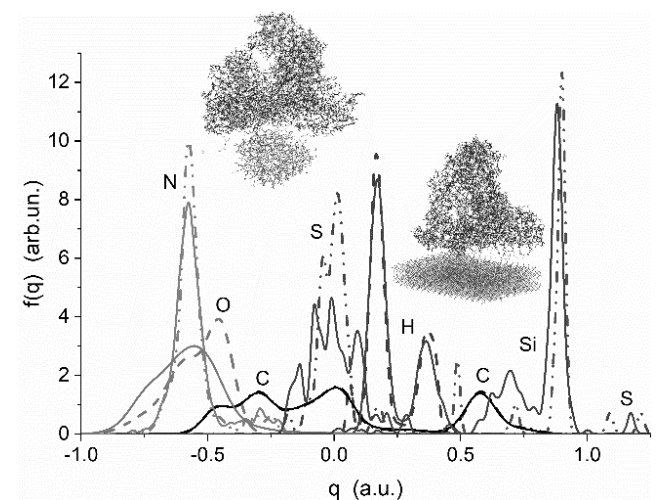

Fig. 7. Charge distribution functions of $\mathrm{H}, \mathrm{C}, \mathrm{N}, \mathrm{O}, \mathrm{Si}$, and $\mathrm{S}$ atoms for HSA with bound 12 molecules of DOX (HSA/DOX), $194 \mathrm{H}_{2} \mathrm{O}$ interacting with a silica nanoparticle $(\sim 3.3 \mathrm{~nm}$ in size) (solid lines, 12304 atoms in total), and HSA/DOX, $149 \mathrm{H}_{2} \mathrm{O}$, interacting with a plane fragment of a silica surface (dashed lines, 15147 atoms in total) calculated using the PM7 method

The structure of silica particles can affect the $\mathrm{CDF}$ of certain atoms (e.g., S) in complex adsorbates such as HSA with DOX (Fig. 7). For some other atoms, the difference could be smaller due to stronger averaging of the $q$ values for larger numbers of atoms. This result may be also explained by a small contact area between silica particles and HSA/DOX/water (Fig. 7, inserts). Additionally, the silica surface shape, hydrophilicity and other characteristics can affect folding-unfolding processes characteristic for proteins and other complex macromolecules.

\section{CONCLUSION}

Thus, calculations of the distribution functions of atomic charges with the DFT and semiempirical PM7 methods may be considered as a simple tool to analyze various factors affecting the electronic structure of complex systems. The efficiency and accuracy of this tool depends strongly on the quality and appropriateness of the models used. The systems with dozens or hundreds of molecules of water or other low-molecular weight compounds (modeling a liquid phase or interfacial layers) and solid nanoparticles of almost real sizes ( $>40$ units, $>2 \mathrm{~nm}$ ) for fumed oxides give more accurate and representative results than the systems with several molecules and too small solid clusters $(<20$ units, $<1 \mathrm{~nm}$ ). As a whole, the presented approach could be used with different quantum chemical methods (ab initio, DFT, and even such semiempirical methods as PM7 or PM6).

\section{ACKNOWLEDGEMENT}

The author is grateful to the National Research Foundation of Ukraine ("Support of advanced and young scientists", grant 2020.02/0057) for financial support of the study. 


\title{
Функції розподілу зарядів для характеризації складних систем
}

\author{
В.М. Гунько
}

Інститут хімії поверхні ім. О.О. Чуйка Національної академії наук Украӥни вул. Генерала Наумова, 17, Київ,03164, Україна, vlad_gunko@ukr.net

\begin{abstract}
Набір характеристик, розрахований у межах методів квантової хімії, може бути віднесений до локальних, щзо змінюються від атома до атома в складних системах. Просте усереднення пов'язаних значень дає досить погані характеристики систем, оскільки різні фракиї певних атомів можуть мати різне оточення $i$, отже, різні характеристики, які не відповідають середньому. Метою цьього дослідження є пошук більш адекватного шляху трансформації локальних характеристик, наприклад, атомних зарядів, у нелокальні на основі функцій розподілу. Функиії розподілу атомних зарядів (CDF) можна розглядати як простий інструмент для аналізу неоднорідних складних систем, оскільки специффічність різних фракцій відображається у формі CDF. В цілому точність та ефективність підходу залежать від якості та доиільності використовуваних молекулярних та кластерних моделей, а також від квантово-хімічних методів (ab initio, DFT та напівемпіричних) та використаних базисних наборів. Наносистеми з десятками молекул (кластери, домени, нанокрапельки), щзо моделюють рідку фазу або міжфразний шар, і тверді наночастинки майже реальних розмірів (> 40 одиниць) можуть розглядатися як більш відповідні моделі реальних систем, ніж моделі з декількома молекулами і невеликими кластерами (< 10 одиниџь). Цей підхід був застосований до представників таких різноманітних матеріалів, як активоване вугілля, пористі та непористі наночастинки кремнезему, немодифіковані та модифіковані з адсорбованими молекулами азоту, метану, води, людський сироватковий альбумін з молекулами доксорубіцину. Цей підхід може надати інформацію, корисну при аналізі будь-яких складних систем.
\end{abstract}

Ключові слова: атомні заряди, функиії розподілу, DFT метод, напівемпіричні методи

\section{REFERENCES}

1. Weinhold F., Landis C.R. Discovering Chemistry with Natural Bond Orbitals. (New York: John Wiley \& Sons. 2012).

2. Helgaker T., Jorgensen P., Olsen J. Molecular Electronic Structure Theory. (New York: John Wiley \& Sons, 2014).

3. Barone V. Computational Strategies for Spectroscopy: from Small Molecules to Nano Systems. (New York: John Wiley \& Sons, 2011).

4. Martin R.M., Reining L., Ceperley D.M. Interacting Electrons: Theory and Computational Approaches. (UK: Cambridge University Press, 2016).

5. Engel E., Dreizler R.M. Density Functional Theory: An Advanced Course. (Springer, 2013).

6. Bruneval F. Assessment of the linearized GW density matrix for molecules. J. Chem. Theory Comput. 2019. 15(7): 4069.

7. Li J., D’Avino G., Duchemin I., Beljonne D., Blase X. Combining the many-body GW formalism with classical polarizable models: Insights on the electronic structure of molecular solids. J. Phys. Chem. Lett. 2016. 7(14): 2814.

8. Sethio D., Raggi G., Lindh R., Erdélyi M. Halogen bond of halonium ions: benchmarking DFT methods for the description of NMR chemical shifts. J. Chem. Theory Comput. 2020. 16(12): 7690.

9. Grimme S., Bannwarth C., Shushkov P. A robust and accurate tight-binding quantum chemical method for structures, vibrational frequencies, and noncovalent interactions of large molecular systems parametrized for all spd-block elements $(Z=1-86)$. J. Chem. Theory Comput. 2017. 13(5): 1989.

10. Gun'ko V.M., Turov V.V. Nuclear Magnetic Resonance Studies of Interfacial Phenomena. (Boca Raton: CRC Press, 2013).

11. Gun'ko V.M. Modeling of interfacial behavior of water and organics. J. Theor. Comput. Chem. 2013. 12(07): 1350059.

12. Gun'ko V.M. Interfacial phenomena: effects of confined space and structure of adsorbents on the behavior of polar and nonpolar adsorbates at low temperatures. Current Physical Chemistry. 2015. 5(2): 137. 
13. Gun'ko V.M. Effects of methods and basis sets on calculation results using various solvation models. Him. Fiz. Tehnol. Poverhni. 2018. 9(1): 3.

14. Frisch M.J., Trucks G.W., Schlegel H.B., Scuseria G.E., Robb M.A., Cheeseman J.R., Scalmani G., Barone V., Mennucci B., Petersson G.A., Nakatsuji H., Caricato M., Li X., Hratchian H.P., Izmaylov A.F., Bloino J., Zheng G., Sonnenberg J.L., Hada M., Ehara M., Toyota K., Fukuda R., Hasegawa J., Ishida M., Nakajima T., Honda Y., Kitao O., Nakai H., Vreven T., Montgomery J.A., Peralta J.E., Ogliaro F., Bearpark M., Heyd J.J., Brothers E., Kudin K.N., Staroverov V.N., Kobayashi R., Normand J., Raghavachari K., Rendell A., Burant J.C., Iyengar S.S., Tomasi J., Cossi M., Rega N., Millam J.M., Klene M., Knox J.E., Cross J.B., Bakken V., Adamo C., Jaramillo J., Gomperts R., Stratmann R.E., Yazyev O., Austin A.J., Cammi R., Pomelli C., Ochterski J.W., Martin R.L., Morokuma K., Zakrzewski V.G., Voth G.A., Salvador P., Dannenberg J.J., Dapprich S., Daniels A.D., Farkas Ö., Foresman J.B., Ortiz J.V., Cioslowski J., Fox D.J. Gaussian 09, Revision D.01. (Gaussian, Inc. Wallingford CT, 2013).

15. Barca G.M.J., Bertoni C., Carrington L., Datta D., De Silva N., Deustua J.E., Fedorov D.G., Gour J.R., Gunina A.O., Guidez E., Harville T., Irle S., Ivanic J., Kowalski K., Leang S.S., Li H., Li W., Lutz J.J., Magoulas I., Mato J., Mironov V., Nakata H., Pham B.Q., Piecuch P., Poole D., Pruitt S.R., Rendell A.P., Roskop L.B., Ruedenberg K. Recent developments in the general atomic and molecular electronic structure system. J. Chem. Phys. 2020. 152: 154102.

16. Marenich A.V., Cramer C.J., Truhlar D.G. Universal solvation model based on solute electron density and on a continuum model of the solvent defined by the bulk dielectric constant and atomic surface tensions. J. Phys. Chem. B. 2009. 113(18): 6378.

17. Yang K., Zheng J., Zhao Y., Truhlar D.G. Tests of the RPBE, revPBE, $\tau$-HCTHhyb, $\omega$ B97X-D, and MOHLYP density functional approximations and 29 others against representative databases for diverse bond energies and barrier heights in catalysis. J. Chem. Phys. 2010. 132(16): 164117.

18. Becke A.D. Perspective: Fifty years of density-functional theory in chemical physics. J. Chem. Phys. 2014. 140(18): 18A301.

19. Stewart J.J.P. MOPAC2016. Stewart Computational Chemistry, web: HTTP://OpenMOPAC.net. January 5, 2021.

20. Stewart J.J.P. Optimization of parameters for semiempirical methods VI: more modifications to the NDDO approximations and re-optimization of parameters. J. Mol. Mod. 2013. 19(1): 1.

21. Gun'ko V.M. Dynamics of chemical bonds and local density of electron states at heterogeneous surfaces. Colloids Surf. A: Physicochem. Eng. Aspects. 1995. 101(2-3): 279.

22. Turov V.V., Gun'ko V.M., Krupska T.V., Borysenko M.B., Kartel M.T. Interfacial behavior of polar and nonpolar frozen/unfrozen liquids interacting with hydrophilic and hydrophobic nanosilicas alone and in blends. J. Colloid Interface Sci. 2021. 588: 70. 